\title{
Acceleration Effect of CuCN in Ag Electroplating for Ultralarge-Scale Interconnects
}

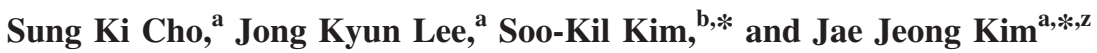 \\ ${ }^{a}$ Research Center for Energy Conversion and Storage, School of Chemical and Biological Engineering, \\ Seoul National University, Kwanak-gu, Seoul 151-742, Korea \\ ${ }^{b}$ Center for Fuel Cell Research, Korea Institute of Science and Technology, Sungbuk-gu, Seoul 136-791, \\ Korea
}

\begin{abstract}
The addition of $\mathrm{CuCN}$ accelerated the deposition rate in cyanide-based Ag electroplating. The catalytic effect came from the high-order complexation of $\mathrm{Cu}$ with the free $\mathrm{CN}^{-}$ions in electrolyte. It changed the equilibrium state of the electrolyte, presented as an increase in the amount of $\mathrm{Ag}(\mathrm{CN})_{2}^{-}$compared to $\mathrm{Ag}(\mathrm{CN})_{3}^{2-}$. Because $\mathrm{Ag}(\mathrm{CN})_{2}^{-}$could be reduced more easily, $\mathrm{Ag}$ electroplating was accelerated. Fourier transform infrared analysis showed the equilibrium change with the increase in $\mathrm{Ag}(\mathrm{CN})_{2}^{-} \mathrm{peak}$ according to the $\mathrm{CuCN}$ addition. For superfilling, it is necessary to localize the complexation on the $\mathrm{Cu}$ surface. (C) 2007 The Electrochemical Society. [DOI: 10.1149/1.2769103] All rights reserved.
\end{abstract}

Manuscript submitted May 17, 2007; revised manuscript received June 21, 2007. Available electronically August 3, 2007.

While $\mathrm{Cu}$ has been introduced successfully in microprocessors by damascene electroplating, Ag has a high potential for a nextgeneration interconnect material in ultralarge-scale interconnects (ULSI) because it has the lowest resistivity ${ }^{1}$ and superior resistance in electromigration. ${ }^{2-7}$

Defect-free superfilling is essential for reliable metal interconnects in damascene electroplating and it is attained by the addition of a catalytic accelerator in the electrolyte. In $\mathrm{Cu}$ electroplating, accelerators on the $\mathrm{Cu}$ surface are accumulated at the trench-inside due to the reduction in the surface area at the concave of trench with the deposition. Locally crowded accelerator in the trench enhances the deposition rate and makes the superfilling. ${ }^{8-10}$ Some organic accelerators, for example, 3-mercapto-1-propane-sulfonic acid (MPSA),, $11-13$ bis(3-sulfopropyl) disulfide, disodium salt (SPS), $, 10,12,14,15$ and 3-N,N-dimethylaminodithiocarbamoyl-1propanesulfonic acid (DPS) ${ }^{16}$ are known as superfilling-capable accelerators. In Ag electroplating, there has been little research about accelerators. Our previous research showed successful Ag superfilling with benzotriazole (BTA) as an accelerator and thiourea as a suppressor in cyanide-based Ag electroplating. ${ }^{4}$ Baker et al. ${ }^{6,7}$ investigated the electrochemical characteristics and filling properties of $\mathrm{SeCN}^{-}$as a single catalytic additive in cyanide-based $\mathrm{Ag}$ electroplating. Nevertheless, it is difficult to develop the various accelerators or to understand the reaction mechanism of the accelerator because the electroplating system of cyanide-based electrolyte is complex.

In this study, $\mathrm{CuCN}$ was developed as an accelerator in cyanidebased $\mathrm{Ag}$ electroplating. Its acceleration effect and the reaction mechanism were investigated through electrochemical and spectroscopic analyses.

\section{Experimental}

Substrates used herein were planar Si wafers with the structure of Ag \{physical vapor deposition (PVD), $100 \mathrm{~nm}$ \}/TiN \{chemical vapor deposition (CVD), $10 \mathrm{~nm}$ \}/Ti (PVD, $15 \mathrm{~nm}$ )/Si(100).

Ag electroplating was carried out with the cyanide-base electrolyte consisting of potassium $\mathrm{Ag}(\mathrm{I})$ cyanide $\left[\mathrm{KAg}(\mathrm{CN})_{2}, 0.92 \mathrm{M}\right]$ and potassium cyanide $(\mathrm{KCN}, 1.1 \mathrm{M}) .500 \mathrm{~mL}$ of electrolyte was prepared for the plating. $\mathrm{CuCN}$ was added in the electrolyte with various concentrations in the range of $0-200 \mathrm{mM}$. As $\mathrm{CuCN}$ was added, the plating was performed within $10 \mathrm{~min}$. The working electrode of $1 \mathrm{~cm}^{2}$ area was the $\mathrm{Ag}$ seeded substrate. An $\mathrm{Ag}$ wire (99.999\%) and saturated calomel electrode (SCE) were used as a counter and a reference electrode, respectively. The deposition was conducted under the potentiostatic condition of $-800 \mathrm{mV}$ (vs SCE)

* Electrochemical Society Active Member
${ }^{\mathrm{z}}$ E-mail: jjkimm@ @nu.ac.kr using PAR 263A potentiostat (EG\&G Princeton Applied Research Corporation). The deposition was carried out for $60 \mathrm{~s}$ without agitation. After the deposition, the substrates were rinsed with deionized water and dried with $\mathrm{N}_{2}$ gas blowing.

The acceleration effect of $\mathrm{CuCN}$ was observed through the monitoring of deposition thickness and electrochemical linear sweep voltammetry (LSV) according to the $\mathrm{CuCN}$ addition. The deposition thickness was measured with field-emission-scanning electron microscope (FESEM, JSM-6330F, JEOL). The LSV analyses were performed on a round $\mathrm{Ag}$ electrode with an area of $0.0314 \mathrm{~cm}^{2}$ in the stagnant electrolyte condition. In each LSV analysis, the potential was swept in the range of -0.65 to $-1.50 \mathrm{~V}$ (vs SCE) with a scan rate of $10 \mathrm{mV} / \mathrm{s}$. Fourier transform infrared (FTIR) spectrometer analyses (Spectrum RX1, Perkin-Elmer) were also carried out on the electrolyte of Ag electroplating in order to observe the change in the electrolyte with $\mathrm{CuCN}$ addition. The peak positions of the $\mathrm{Cu}$ and Ag cyanide complexes are listed in Table I. The depth profile of the $\mathrm{Ag}$ film electroplated in the presence of $\mathrm{CuCN}$ was analyzed with Auger electron spectroscopy (AES, model 660, Perkin-Elmer).

\section{Results and Discussion}

Figure 1 shows the cross-sectional FESEM images of Ag films electroplated for $60 \mathrm{~s}$ at $-800 \mathrm{mV}$ (vs SCE) with the addition of $\mathrm{CuCN}$ (Fig. 1a-c) and the deposition rate according to the concentration of $\mathrm{CuCN}$ (Fig. 1d). When $186 \mathrm{mM}$ of $\mathrm{CuCN}$ was added to the electrolyte (Fig. 1c), the film thickness increased by about $60 \%$ compared to the film deposited without $\mathrm{CuCN}$ (Fig. 1a). The deposition rate increased with the concentration of $\mathrm{CuCN}$ (Fig. 1d). The AES depth profile of Ag film electroplated with $\mathrm{CuCN}$ showed no $\mathrm{Cu}$ atoms in the film, which meant that the increase in the deposition rate was not originated from the codeposition of $\mathrm{CuCN}$ and it acted as an additive (Fig. 2). The acceleration effect of $\mathrm{CuCN}$ in deposition was also shown in the electrochemical LSV analysis (Fig. 3).

\begin{tabular}{|c|c|c|}
\hline Species & State & Wavenumber $\left(\mathrm{cm}^{-1}\right)$ \\
\hline $\mathrm{Ag}(\mathrm{CN})_{2}^{-}$ & Aqueous & $2135 \pm 1$ \\
\hline $\mathrm{Ag}(\mathrm{CN})_{3}^{2-}$ & Aqueous & $2105 \pm 1$ \\
\hline $\mathrm{Ag}(\mathrm{CN})_{4}^{3-}$ & Aqueous & $2092 \pm 1$ \\
\hline $\mathrm{Cu}(\mathrm{CN})_{2}^{-}$ & Aqueous & $2125 \pm 3$ \\
\hline $\mathrm{Cu}(\mathrm{CN})_{3}^{2-}$ & Aqueous & $2094 \pm 1$ \\
\hline $\mathrm{Cu}(\mathrm{CN})_{4}^{3-}$ & Aqueous & $2076 \pm 1$ \\
\hline $\mathrm{CN}^{-}$ & Aqueous & $2080 \pm 2$ \\
\hline $\mathrm{CuCN}$ & Solid & $2172 \pm 1$ \\
\hline $\mathrm{AgCN}$ & Solid & $2164 \pm 1$ \\
\hline
\end{tabular}



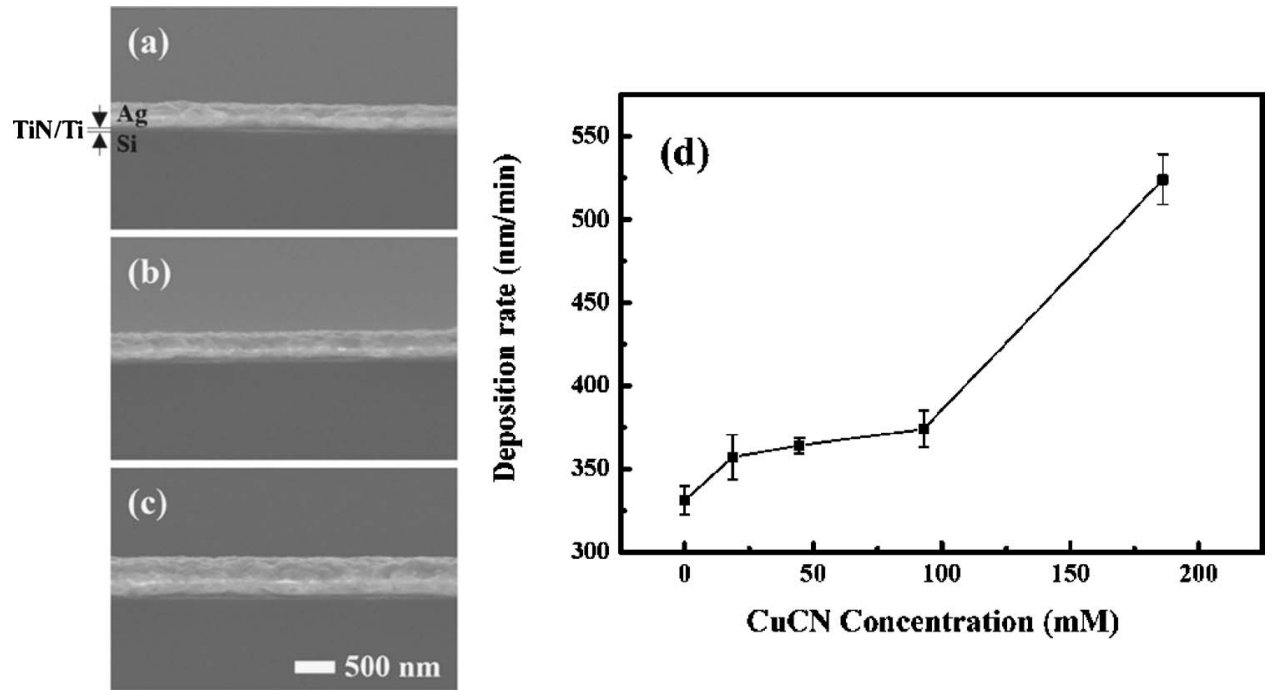

Figure 1. Cross-sectional FESEM images of Ag electrodeposited under the potentiostatic condition of $-800 \mathrm{mV}$ (vs SCE) for $60 \mathrm{~s}$ (a) without $\mathrm{CuCN}$, (b) with $44.6 \mathrm{mM}$ of $\mathrm{CuCN}$, and (c) with $186.0 \mathrm{mM}$ of $\mathrm{CuCN}$. (d) $\mathrm{Ag}$ deposition rate according to the $\mathrm{CuCN}$ concentration evaluated by measuring the electroplated Ag film thickness.

Although the current curve of $44.6 \mathrm{mM}$ was similar to that of $18.6 \mathrm{mM}$, the current increased gradually as $\mathrm{CuCN}$ was added to the electrolyte in the potential range up to $-1.0 \mathrm{~V}$. However, over the potential of $-1.0 \mathrm{~V}$, the LSV curves crossed due to hydrogen

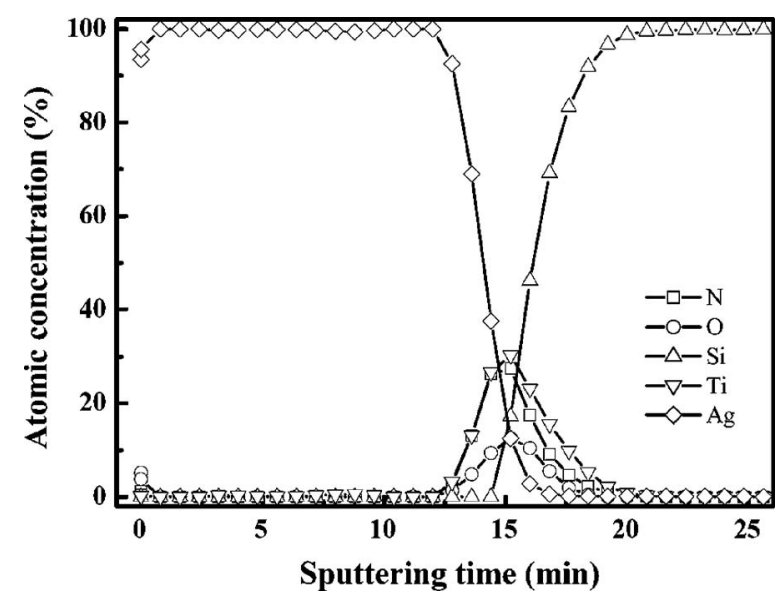

Figure 2. AES depth profile of Ag film deposited with $93.0 \mathrm{mM}$ of $\mathrm{CuCN}$.

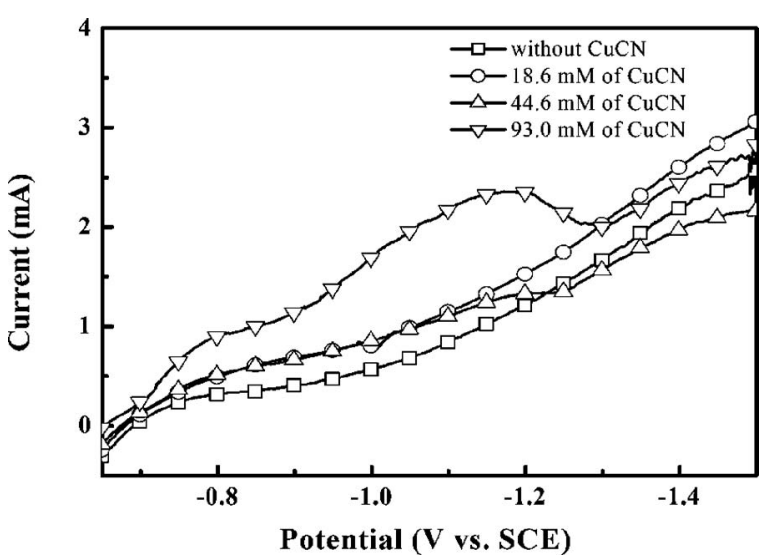

Figure 3. $\mathrm{LSV}$ with the addition of $\mathrm{CuCN}$ on $\mathrm{Ag}$ electrode. The potential was swept with the scan rate of $10 \mathrm{mV} / \mathrm{s}$ in the range of -0.65 to $-1.50 \mathrm{~V}$ (vs SCE). evolution. ${ }^{18}$ Still, it was obvious that the addition of $\mathrm{CuCN}$ led to the increase in current at $-0.8 \mathrm{~V}$, at which all depositions in this study were performed.

In cyanide-based Ag electroplating, various $\mathrm{Ag}$ complexes such as $\mathrm{Ag}(\mathrm{CN})_{2}^{-}$and $\mathrm{Ag}(\mathrm{CN})_{3}^{2-}$ exist in the electrolyte. The predominant species involved in the charge-transfer reaction depends on $\mathrm{CN}^{-}$ concentration with the following equilibrium ${ }^{19,20}$

$$
\mathrm{Ag}(\mathrm{CN})_{3}^{2-}(\mathrm{aq}) \leftrightarrow \operatorname{Ag}(\mathrm{CN})_{2}^{-}(\mathrm{aq})+\mathrm{CN}^{-}(\mathrm{aq})
$$

According to Eq. 1, as $\mathrm{CN}^{-}$concentration decreases, the main species in the electrolyte changes from $\mathrm{Ag}(\mathrm{CN})_{3}^{2-}$ to $\mathrm{Ag}(\mathrm{CN})_{2}^{-}$. The addition of $\mathrm{CuCN}$ might affect the $\mathrm{CN}^{-}$concentration through the additional high-order complexation of $\mathrm{Cu}$ with the $\mathrm{CN}^{-}$ions, resulting in the change of the equilibrium, the main deposition species, and the deposition mechanism in consequence. The complexation of $\mathrm{Cu}$ in a cyanide system is known to have a high stability constant $(\beta)$ and high equilibrium constant $(K)$, indicating preferential highorder complexation in the electrolyte ${ }^{19,21,22}$

$$
\begin{aligned}
& \mathrm{Cu}^{+}(\mathrm{aq})+2 \mathrm{CN}^{-}(\mathrm{aq}) \leftrightarrow \mathrm{Cu}(\mathrm{CN})_{2}^{-}(\mathrm{aq}) \quad \log \beta_{2}=21.7 \\
& \mathrm{Cu}(\mathrm{CN})_{2}^{-}(\mathrm{aq})+\mathrm{CN}^{-}(\mathrm{aq}) \leftrightarrow \mathrm{Cu}(\mathrm{CN})_{3}^{2-}(\mathrm{aq}) \quad \log K_{3}=4.6 \\
& \mathrm{Cu}(\mathrm{CN})_{3}^{2-}(\mathrm{aq})+\mathrm{CN}^{-}(\mathrm{aq}) \leftrightarrow \mathrm{Cu}(\mathrm{CN})_{4}^{3-}(\mathrm{aq}) \quad \log K_{4}=2.3
\end{aligned}
$$

$\beta_{2}$ is a stability constant of $\mathrm{Cu}(\mathrm{CN})_{2}^{-}$. As $\mathrm{CuCN}$ was dissociated in the electrolyte, the $\mathrm{Cu}^{+}$ion formed the cyanide complexes by consuming free $\mathrm{CN}^{-}$in the solution, so that the amount of $\mathrm{Ag}(\mathrm{CN})_{2}^{-}$ complexes increased and the amount of $\mathrm{Ag}(\mathrm{CN})_{3}^{2-}$ complexes decreased due to the lack of $\mathrm{CN}^{-}$ion according to the equilibrium condition of Eq. 1. It changed in the current generated under the potentiostatic condition because the redox equilibrium potentials $(E)$ of $\mathrm{Ag}(\mathrm{CN})_{2}^{-}$and $\mathrm{Ag}(\mathrm{CN})_{3}^{2-}$ differed as follows ${ }^{23}$

$\mathrm{Ag}(\mathrm{CN})_{3}^{2-}(\mathrm{aq})+\mathrm{e}^{-} \rightarrow \mathrm{Ag}(\mathrm{s})+3 \mathrm{CN}^{-}(\mathrm{aq}) \quad E^{0}=-0.74 \mathrm{~V}(\mathrm{vsSCE})$

$\mathrm{Ag}(\mathrm{CN})_{2}^{-}(\mathrm{aq})+\mathrm{e}^{-} \rightarrow \mathrm{Ag}(\mathrm{s})+2 \mathrm{CN}^{-}(\mathrm{aq}) \quad E^{0}=-0.55 \mathrm{~V}(\mathrm{vsSCE})$

Sufficient $\operatorname{Ag}(\mathrm{CN})_{2}^{-}$in the solution increased the current density at the constant electrode potential because a lower equilibrium potential of $\operatorname{Ag}(\mathrm{CN})_{2}^{-}$resulted in a higher overpotential in the reduction for electroplating. Namely, the change in the equilibrium state of the electrolyte by adding $\mathrm{CuCN}$ produced the acceleration effect 


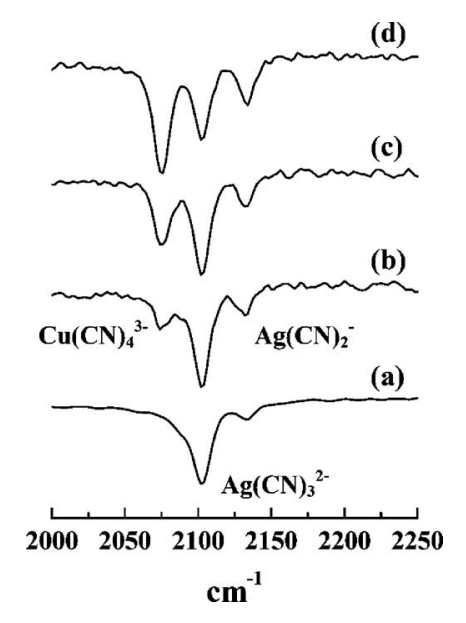

Figure 4. FTIR spectrometer analyses on the cyanide-based electrolyte contained (a) no $\mathrm{CuCN}$, (b) $18.6 \mathrm{mM}$ of $\mathrm{CuCN}$, (c) $44.6 \mathrm{mM}$ of $\mathrm{CuCN}$, and (d) $93.0 \mathrm{mM}$ of $\mathrm{CuCN}$. The wavenumbers of $\mathrm{Cu}(\mathrm{CN})_{4}^{3-}, \mathrm{Ag}(\mathrm{CN})_{3}^{2-}$, and $\mathrm{Ag}(\mathrm{CN})_{2}^{-}$were 2076,2105 , and $2135 \mathrm{~cm}^{-1}$, respectively.

in Ag electroplating. Because the deposition rate depends on the change of the equilibrium, the acceleration would have increased nonlinearly with the concentration of $\mathrm{CuCN}$ as shown in Fig. 1d and LSV data.

FTIR analyses were conducted in order to observe the change in the equilibrium and the complexation of $\mathrm{Cu}$ in the electrolyte (Fig. 4). Various $\mathrm{Ag}$ and $\mathrm{Cu}$ cyanide complexes were detected from the analyses, as shown in the figure. When $\mathrm{CuCN}$ was not added in the electrolyte, a strong $\operatorname{Ag}(\mathrm{CN})_{3}^{2-}$ peak $\left(2105 \mathrm{~cm}^{-1}\right)$ was observed, though the $\operatorname{Ag}(\mathrm{CN})_{2}^{-}$peak $\left(2135 \mathrm{~cm}^{-1}\right)$ was weak. As $\mathrm{CuCN}$ was added in the electrolyte, the intensity of the $\operatorname{Ag}(\mathrm{CN})_{2}^{-}$peak increased. This meant that the addition of $\mathrm{CuCN}$ changed the equilibrium state of the solution and increased the amount of $\mathrm{Ag}(\mathrm{CN})_{2}^{-}$in the electrolyte. This observation was well-matched with the explanation for the change in electrolyte condition due to $\mathrm{CuCN}$. The other peak that increased with $\mathrm{CuCN}$ was related to $\mathrm{Cu}(\mathrm{CN})_{4}^{3-}$ $\left(2076 \mathrm{~cm}^{-1}\right)$. It came from the complexation of $\mathrm{Cu}^{+}$in the electrolyte, but the peaks related to $\mathrm{Cu}(\mathrm{CN})_{2}^{-}\left(2125 \mathrm{~cm}^{-1}\right)$ and $\mathrm{Cu}(\mathrm{CN})_{3}^{2-}$ were very weak or not observed in analysis, which meant that $\mathrm{Cu}$ was fully complexed with $\mathrm{CN}^{-}$in the electrolyte due to its high stability constant.

Actually, the change in the reaction rate and the equilibrium state in the electrolyte can be modulated by $\mathrm{KCN}$, which is added to stabilize the complex and improve the conductivity of the bath. In particular, $\mathrm{KCN}$ is dissolved to generate the free $\mathrm{CN}^{-}$ion. Because the equilibrium state and predominant species depend on the $\mathrm{CN}^{-}$ concentration, the addition of $\mathrm{KCN}$ affects the equilibrium state of the electrolyte. Accordingly, $(\mathrm{Ag}) /(\mathrm{CN})$, that is, the ratio of the mole concentration of $\mathrm{Ag}$ added in the form of $\mathrm{KAg}(\mathrm{CN})_{2}$ which was maintained as constant in this study to the total amount of $\mathrm{CN}^{-}$ added with $\mathrm{KAg}(\mathrm{CN})_{2}$ and $\mathrm{KCN}$, could represent the equilibrium state of the electrolyte. A higher $(\mathrm{Ag}) /(\mathrm{CN})$ value means a relatively low amount of $\mathrm{CN}^{-}$, so a high amount of $\mathrm{Ag}(\mathrm{CN})_{2}^{-}$could be expected in the solution. The equilibrium changes with $(\mathrm{Ag}) /(\mathrm{CN})$ values were observed with FTIR and electrochemical analyses, as shown in Fig. 5. Figure 5a shows FTIR analyses on the electrolytes with various $(\mathrm{Ag}) /(\mathrm{CN})$ values. At the high value of $(\mathrm{Ag}) /(\mathrm{CN})$, the peak of $\mathrm{Ag}(\mathrm{CN})_{2}^{-}$becomes clear. Except for the absence of the $\mathrm{Cu}$ complex peak, the FTIR results were similar to those of the $\mathrm{CuCN}$ additions (Fig. 4). In other words, the change in the electrolyte condition with the $\mathrm{CuCN}$ addition was equal to the change in the equilibrium state with $\mathrm{CN}^{-}$concentration. Figure 5 b shows the variation of the deposition rate with the $(\mathrm{Ag}) /(\mathrm{CN})$ value. The deposition rate
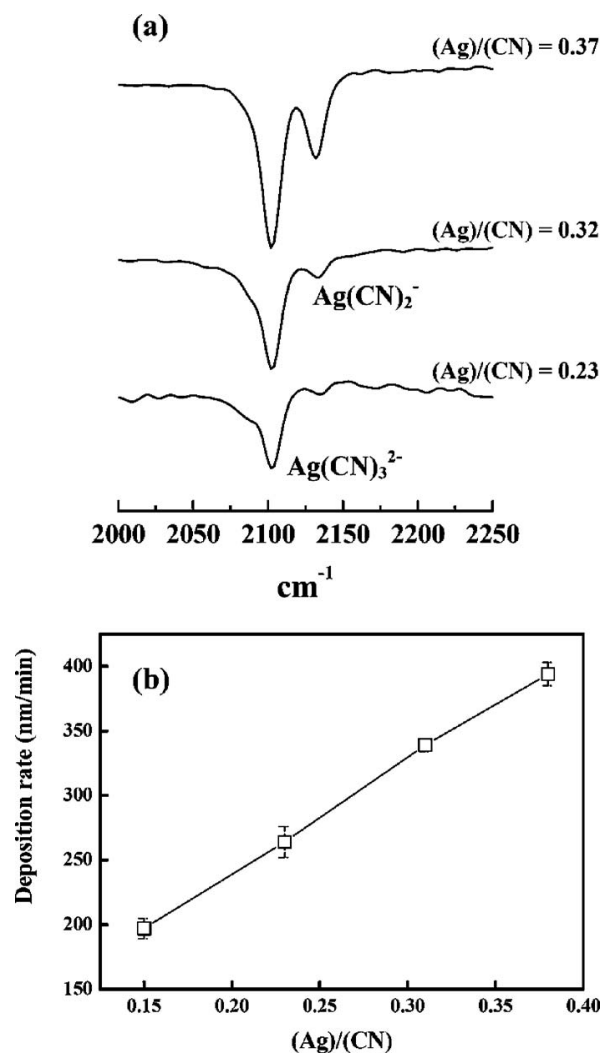

Figure 5. (a) FTIR spectrometer analyses on the cyanide-based electrolyte with various $(\mathrm{Ag}) /(\mathrm{CN})$ values $[(\mathrm{Ag}) /(\mathrm{CN})=0.23,0.32$, and 0.37$]$ and $(\mathrm{b})$ the deposition rate according to $(\mathrm{Ag}) /(\mathrm{CN})$. $(\mathrm{Ag}) /(\mathrm{CN})$ value is the total mole concentration of $\mathrm{Ag}$ added with $\mathrm{KAg}(\mathrm{CN})_{2}$ over the total amount of $\mathrm{CN}^{-}$added with $\mathrm{KAg}(\mathrm{CN})_{2}$ and $\mathrm{KCN}$.

increased with the $(\mathrm{Ag}) /(\mathrm{CN})$ value because many $\mathrm{Ag}(\mathrm{CN})_{2}^{-}$complexes, which could be reduced more easily compared to $\operatorname{Ag}(\mathrm{CN})_{3}^{2-}$, were generated. This evidence makes it clear that the equilibrium change by $\mathrm{CuCN}$ can vary the deposition rate.

The addition of $\mathrm{CuCN}$ consumed the free $\mathrm{CN}^{-}$in the electrolyte due to its complexation with $\mathrm{CN}^{-}$, leading to a change in the equilibrium state of the electrolyte and $\mathrm{Ag}(\mathrm{CN})_{2}^{-}$dominated over $\mathrm{Ag}(\mathrm{CN})_{3}^{2-}$ in the cyanide-poor electrolyte state. When $93.0 \mathrm{mM}$ of $\mathrm{CuCN}$ was added to the base electrolyte $\left[0.92 \mathrm{M} \mathrm{KAg}(\mathrm{CN})_{2}, 1.1 \mathrm{M}\right.$ $\mathrm{KCN}$ ], $279.0 \mathrm{mM}$ of free $\mathrm{CN}^{-}$was consumed, assuming a full complexation as $\mathrm{Cu}(\mathrm{CN})_{4}^{3-}$. As a result, the $(\mathrm{Ag}) /(\mathrm{CN})$ value in the electrolyte changed from 0.313 to 0.346 . The change was related to the approximate deposition rate of $370 \mathrm{~nm} / \mathrm{min}$, described in Fig. $5 \mathrm{~b}$, and it was similar to the real deposition rate of $374 \pm 11 \mathrm{~nm} / \mathrm{min}$ generated with $93.0 \mathrm{mM}$ of $\mathrm{CuCN}$, as shown in Fig. 1d. This simple calculation can support the above-mentioned explanation of the phenomena of the catalytic effect of $\mathrm{CuCN}$.

Until now, it was electrochemically and spectroscopically observed that the acceleration effect of $\mathrm{CuCN}$ ( $\mathrm{Cu}$ ion to be exact) came from high-order complexation of $\mathrm{Cu}$ with free cyanide. However, it might not generate the local variation of the deposition rate and subsequent superfilling, because the complexation is related not to the surface but to bulk electrolyte. But it is possible to achieve superfilling if the complexation is bound on the surface. For example, $\mathrm{Cu}$ seed can be used as a complexing source. Baker et al. ${ }^{6}$ reported the dissolution of $\mathrm{Cu}$ seed in cyanide bath. Dissolved $\mathrm{Cu}$ ions can form high-order $\mathrm{Cu}$ cyanide complex as does $\mathrm{CuCN}$. The $\mathrm{Cu}$ ions concentrated at trench-inside consume cyanide ions, enhance the local deposition rate, and finally make superfilling. This will be evaluated in succeeding research. 


\section{Conclusions}

When $\mathrm{CuCN}$ was added in cyanide-based $\mathrm{Ag}$ electroplating, the deposition rate increased without incorporation of $\mathrm{Cu}$. In the FTIR analyses, it was observed that $\mathrm{CuCN}$ changed the equilibrium state by consuming the free $\mathrm{CN}^{-}$due to the formation of the $\mathrm{Cu}$ cyanide complex, $\mathrm{Cu}(\mathrm{CN})_{4}^{3-}$, in the electrolyte. A similar change in the equilibrium state, accomplished by varying the compositions of the electrolyte, showed a change in the deposition rate in electroplating. It was concluded that $\mathrm{CuCN}$ changed the equilibrium state and species that participated in the reduction, so that it varied the deposition rate.

\section{Acknowledgments}

This work was supported by the Korea Science and Engineering Foundation through the Research Center for Energy Conversion and Storage (RCECS), Dongbu HiTeK, and also by the Institute of Chemical Processes (ICP). Seoul
article.

Seoul National University assisted in meeting the publication costs of this

\section{References}

1. R. Manepalli, F. Stepniak, S. A. Bidsturp-Allen, and P. A. Kohl, IEEE Trans. Adv. Packag., 22, 4 (1999).

2. M. Hauder, J. Gstöttner, W. Hansch, and D. Schmitt-Landsiedel, Appl. Phys. Lett., 78, 838 (2001).
3. T. L. Alford, Y. Zeng, P. Nguyen, L. Chen, and J. W. Mayer, Microelectron. Eng., 55, 389 (2001).

4. E. J. Ahn and J. J. Kim, Electrochem. Solid-State Lett., 7, C118 (2004).

5. T. P. Moffat, B. Baker, D. Wheeler, J.. E. Bonevich, M. Edelstein, D. R. Kelley, L. Gan, G. R. Stafford, P. J. Chen, W. F. Egelhoff, and D. Josell, J. Electrochem. Soc., 149, C423 (2002).

6. B. C. Baker, C. Witt, D. Wheeler, D. Josell, and T. P. Moffat, Electrochem. SolidState Lett., 6, C67 (2003).

7. B. C. Baker, M. Freeman, B. Melnick, D. Wheeler, D. Josell, and T. P. Moffat, J. Electrochem. Soc., 150, C61 (2003).

8. D. Josell, D. Wheeler, W. H. Huber, and T. P. Moffat, Phys. Rev. Lett., 87, 016102 (2001)

9. J. Reid, J. Appl. Phys., 40, 2650 (2001).

10. A. C. West, S. Mayer, and J. Reid, Electrochem. Solid-State Lett., 4, C50 (2001).

11. J. J. Kim, S.-K. Kim, and Y. S. Kim, J. Electroanal. Chem., 542, 61 (2003).

12. S.-K. Kim and J. J. Kim, Electrochem. Solid-State Lett., 7, C98 (2004).

13. T. P. Moffat, J. E. Bonevich, W. H. Huber, A. Stanishevsky, D. R. Kelly, G. R. Stafford, and D. Josell, J. Electrochem. Soc., 147, 4524 (2000).

14. S.-K. Kim, S. K. Cho, J. J. Kim, and Y.-S. Lee, Electrochem. Solid-State Lett., 8, C19 (2005).

15. T. P. Moffat, D. Wheeler, and D. Josell, J. Electrochem. Soc., 151, C262 (2004)

16. S. K. Cho, S.-K. Kim, and J. J. Kim, J. Electrochem. Soc., 152, C330 (2005).

17. R. A. Penneman and L. H. Jones, J. Chem. Phys., 24, 293 (1956).

18. H. C. Koo, E. J. Ahn, and J. J. Kim, J. Electrochem. Soc., Submitted.

19. A. Gherrou and H. Kerdjoudj, Desalination, 151, 87 (2002).

20. G. Baltrūnas, Electrochim. Acta, 48, 3659 (2003)

21. J. Lu, D. B. Dreisinger, and W. C. Cooper, Hydrometallurgy, 66, 23 (2003)

22. F. A. Lemos, L. G. S. Sobral, and A. J. B. Dutra, Minerals Eng., 19, 388 (2006).

23. A. J. Bard, R. Parsons, and J. Jordan, in Standard Potentials in Aqueous Solution, p. 305, IUPAC, New York (1985) 